\title{
Kota Sungaipenuh sebagai Kota Sentral Batik Incung
}

\author{
Nandia Pitri ${ }^{1}$ \\ ${ }^{1}$ Program Studi Magister Ilmu Sejarah, Fakultas Ilmu Budaya, Universitas Andalas \\ Jl. Limau Manis, Kec. Pauh, Kota Padang, Sumatera Barat 25163, Indonesia \\ Email:nandpitri@gmail.com
}

Received 28 October 2019; Received in revised form 03 January 2020; Accepted 28 February 2020

\begin{abstract}
Abstrak
Penelitian ini bertujuan untuk menjelaskan mengenai batik Incung di Kota Sungaipenuh. Kota Sungaipenuh merupakan salah satu kota penghasil batik di Indonesia. Kota Sungaipenuh sebagai pusat pengembangan kerajinan batik Incung. Batik Incung di Kota Sungaipenuh digunakan oleh masyarakat sebagai aset ekonomi dan identitas budaya. Metode penelitian mengunakan metode penelitian Sejarah yang terdiri dari heuristik, kritik sumber, interpretasi dan penulisan. Batik Incung adalah batik khas Kota Sungaipenuh dengan menjadikan aksara Incung (aksara Kerinci kuno) sebagai motif batiknya. Adanya penggunaan motif aksara Incung menjadikan batik Incung di Kota Sungaipenuh memiliki keunikan dengan mengembangkan kearifan lokal masyarakat setempat. Hal ini dikarenakan masyarakat Kota Sungaipenuh memiliki rasa bangga terhadap batik sebagai sesuatu yang indah untuk dijadikan sebagai karya seni. Pengembangan motif pada batik Incung di Kota Sungaipenuh juga berkaitan dengan adanya budaya setempat.
\end{abstract}

Kata kunci: sentral, batik, Incung, Kota Sungaipenuh

\begin{abstract}
This study aims to explain about Incung batik in Sungaipenuh City. Sungaipenuh City is one of the batik producing cities in Indonesia. Sungaipenuh City as a center for the development of Incung batik. Batik Incung in Sungaipenuh City is used by the community as an economic asset and cultural identity. The research method uses the historical research method which consists of heuristics, source criticism, interpretation and writing. Incung Batik is a typical batik of Sungaipenuh City by making Incung script (ancient Kerinci script) as its batik motif. The use of Incung script makes Incung batik in Sungaipenuh City unique by developing local wisdom of the local community. This is because the people of Sungaipenuh have a sense of pride in batik as something beautiful to be used as a work of art. The development of motifs on Incung batik in Sungaipenuh City is also related to the existence of local culture.

Keywords: central, batik, Incung, Sungaipenuh town.
\end{abstract}

\section{PENDAHULUAN}

Berkembangnya industri kecil di Indonesia, tidak terlepas dari keadaan perekonomian bangsa. Hal ini disebabkan karena industri kecil mempunyai potensi bagi perekonomian negara, terbukanya lapangan pekerjaan serta menyediakan kebutuhan masyarakat dengan harga yang lebih murah dan produsen yang memiliki modal kecil. Perkembangan industri kecil yang berkembang pada saat ini adalah industri batik.

Batik dikenal sebagai salah satu dari wujud kebudayaan. Hal ini disebabkan karena batik di Indonesia merupakan suatu keseluruhan teknik, teknologi, serta pengembangan motif dan budaya yang terkait. Sehingga, UNESCO menetapkan 
bahwa batik sebagai warisan kemanusiaan untuk budaya lisan non-bendawi sejak Oktober 2009(Musman \& Arini, 2011). Setelah pengakuan ini, barulah industri kecik batik di Indonesia mulai berkembang pesat, karena masing-masing daerah ingin mengembangkan kearifan lokal yang ada pada masing-masing daerah di Indonesia melalui motif batik. Hal ini, dikarenakan masing-masing motif batik yang dikembangkan oleh daerah tertentu merupakan kearifan lokal masyarakat setempat tempat batik tersebut dikembangkan.

Motif batik yang dikembangkan di Kota Sungaipenuh adalah motif Incung yang diadopsi dari aksara Incung yang merupakan aksara dalam naskah kuno Kerinci. Hal inilah yang menjadi keunikan batik yang dikembangkan di Kota Sungaipenuh. Selain itu, motif Incung yang berkembang pada batik di Kota Sungaipenuh ini tidak hanya abjad Incung saja tetapi juga menjelaskan suatu benda atau tumbuhan yang terdapat pada kain batik tersebut. Salah satu motifnya adalah Kota Sungaipenuh yang dituliskan dalam aksara Incung dan menjadi motif batik di wilayah ini. dijadikannya Kota Sungaipenuh sebagai motif batik karena sentral atau pusat dari pengembangan industri batik Incung ini adalah di Kota Sungaipenuh. Sehingga, untuk mengapresiasi wilayah ini sebagai sentral batik maka dijadikan sebagai motif batik.
Oleh sebab itu, pada tulisan ini ingin melihat hubungan antara batik Incung dengan wilayah sentral pengembangan batik Incung, dengan beberapa pertanyaan seperti apa yang melatarbelakangi dijadikannya aksara Incung sebagai motif batik di Kota Sungaipenuh? Apa hubungan antara batik Incung dengan Kota Sungaipenuh sebagai sentral batik? Siapakah tokoh yang berperan penting dalam pengembangan batik Incung di Kota Sungaipenuh?

\section{METODE}

Penelitian ini menggunakan metode sejarah yang dibagi ke dalam empat tahapan, yakni heuristik, kritik, interpretasi dan historiografi (Gottschalk, 2007). Metode sejarah adalah proses menguji dan menganalisis secara kritis rekaman peninggalan masa lampau berdasarkan data yang diperoleh dengan menempuh proses yang berwujud historiografi. Dalam hal ini metode sejarah digunakan agar dapat merekonstruksi kembali peristiwa masa lampau, sehingga dapat di uji kebenarannya(Zed, 1999).

Tahap pertama, yakni heuristik (pengumpulan sumber). Sumber-sumber yang didapatkan dari hasil studi perpustakaan dan hasil wawancara dengan pelaku sejarah yang dapat dijadikan sebagai informan. Studi pustaka dilakukan ke berbagai perguruan tinggi yang ada di Sumatera Barat, khsusnya 
HISTORIA : Jurnal Program Studi Pendidikan Sejarah Volume 8 (1) 2020

ISSN 2337-4713 E-ISSN2442-8728

Kota Padang. Seperti penelusuran pustaka

pusat Universitas Andalas, pustaka pascasarjana Universitas Andalas, pustaka jurusan Magister Universitas Andalas serta pustaka pusat Universitas Negeri Padang, kemudian tak ketinggalan perpustakaan daerah Sumatera Barat. Arsip dan perpustakaan Kerinci, selanjutnya sumber penting lainnya dapat ditemukan di kantor Dinas Perindustrian dan Perdagangan Kabupaten Kerinci dan Kota Sungaipenuh, Badan Pusat Statistik Kabupaten Kerinci dan Kota Sungaipenuh, dan Dinas Parawisata Kabupaten Kerinci dan Kota Sungaipenuh.

Selain menggunakan Sumber tulisan, sumber lisan yaitu wawancara dilakukan kepada pelaku sejarah yang masih hidup yang terlibat langsung dengan penelitian yang dilakukan. Diantaranya, Elita Jaya, Deli Iryani, Erni Yusnita, Depati H. Alimin.

Setelah sumber data terkumpul, langkah selanjutnya adalah dengan melakukan kritik sumber melalui kritik ekstern dan kritik intern agar memperoleh kredibilitas dan otentisitas. Fakta sejarah kemudian diinterpretasikan atau penafsiran sesuai dengan pendekatan budaya. Tahap terakhir adalah historiografi yaitu penulisan faktafakta yang diperoleh dari data-data yang ada. Proses penulisan dapat disatukan sehingga menjadi satu perpaduan yang sistematis dalam bentuk narasi kronologis (Sjamsuddin, 2007).

\section{HASIL DAN PEMBAHASAN}

Aksara Incung sebagai Motif Batik di Kota Sungaipenuh

Sumatera memiliki salah satu peninggalan peradaban masa lalu yaitu aksara Incung yang terdapat di wilayah Kerinci. Adanya aksara Incung ini di Kerinci menjdi salah satu bentuk keragaman kebudayaan yang dimiliki oleh suku Kerinci. Aksara Incung dahulunya digunakan untuk menulis sastra, hukum adat dan mantra yang dituliskan pada tanduk kerbau, tanduk sapi, kulit kayu, bambu dan daun lontar(Djakfar \& Indra, 2001).Di Sumatra terdapat 4 wilayah yang menjadi pusat penyebaran aksara kuno ini yaitu Batak, Kerinci, Rejang dan Lampung. Bahasa yang digunakan dalam aksara kuno tersebut menggunakan bahasa Melayu kuno. Hal ini dikarenakan bahasa Kerinci kuno (aksara Incung) merupakan bagian dari bahasa Melayu yang menyebar dari Madagaskar sampai ke lautan Pasifik(Kebudayaan, 2003).

Naskah Undang-Undang Tanjung Tanah yang dituliskan pada abad ke-18 M dikatakan oleh Uli Kozok sebagai naskah Melayu tertua di dunia. Kozok juga menjelaskan bahwa aksara Incung ini digunakan oleh suku Kerinci jauh sebelum Islam masuk ke wilayah ini(Gottschalk, 2007).Incung merupakan bahasa Kerinci yang memiliki arti miring atau seperti terpancung yang dibentuk oleh garis lurus dan melengkung serta memiliki kemiringan $45^{\circ}$. Aksara Incung Kerinci ini 
sebagai hasil budaya yang memiliki nilai filosofis, simbolik, fungsi dan nilai sejarah yang berwawasan budaya lokal dan bernilai tradisi.

Asal usul aksara Incung di Kerinci ini, terdapat dua pendapat. Pertama, berasal dari India dan Cina, karena menurut Harimurti Kridalaksana menyebutkan bahwa aksara Incung berasal dari India selatan yang dipengaruhi oleh bangsa Tamil. Kedua, aksara Incung berkembang karena adanya hubungan politik dan kebudayaan antara Kerinci dan Jambi serta Minangkabau. Hal ini dikarenakan Kerinci menjadi tempat pertemuan raja-raja dan merupakan daerah perbatasan yang rawan, maka untuk menandatangani perjanjian di tulis dalam bentuk aksara Incung. Hal inilah yang diyakini menjadi dasar suku Kerinci memiliki aksara sendiri dalam menulis(Zakaria \& Syaputra, 2017).

Pengenalan aksara Incung kepada masyarakat dilakukan dengan beberapa, yaitu dengan adanya pengajaran di sekolah melalui pelajaran muatan lokal serta semakin dikenal oleh mastarakay setelah dijadikan sebagai motif batik di Kota Sungaipenuh maupun di Kabupaten Kerinci.

Terciptanya karya seni dipengaruhi oleh latar belakang budaya suatu masyarakat yang telah di olah, diberi bentuk dan bersifat baku yang memiliki nilai filosofis dan simbol etis. Landasan penciptaan aksara Incung menjadi motif batik di Kota Sungaipenuh merupakan peran pemerintah Provinsi Jambi yang diwakili oleh Departemen Perindustrian Provinsi Jambi (sekarang Dinas Perindustrian dan Perdagangan) yang diketuai oleh Djamil Usman. Pada tahun 1993 dinas ini mengutuskan Ida Maryanti untuk membuat batik dengan motif khusus untuk daerah Kerinci. Ida Maryanti menjelaskan bahwa setiap daerah harus memiliki identitas sendiri dalam mengembangkan motif batik, karena di Kerinci memiliki aksara Incung sebagai bentuk keragaman kebudayaan maka ia berinisiatif untuk mengembangkan batik di wilayah Kerinci dengan motif aksara Incung. Ida Maryani beranggapan bahwa Incung diartikan sebagai bahasa dan seni, yang ketika dituangkan ke dalam kain batik maka akan membuat masyarakat lebihi mudah dalam memahami maknanya(Maryanti, 2018). Pada tahun 1994, Djamil Usman sebagai ketua Departemen Perindustrian Mangundang tim kreatif dari Jakarta untuk memperkenalkan batik Incung Kerinci melalui fashion show dengan mendatangkan model dari Jakarta(Kompas, 19994).

Batik di Kota Sungaipenuh terlihat mempunyai keunikan jika dibandingkan dengan batik yang ada di daerah lainnya karena batik di Kota Sungaipenuh ini menggunakan aksara Incung di setiap motifnya yang motif batiknya bersumber pada bentuk geometris, alam dan aksara 
HISTORIA : Jurnal Program Studi Pendidikan Sejarah Volume 8 (1) 2020

ISSN 2337-4713 E-ISSN2442-8728

Kerinci. Ada beberapa motif batik yang dikembangkan di Kota Sungaipenuh, seperti aksara Incung, biloik (lumbung padi), pucuk kayu, jangki terawang, carano, keluk paku, daun sirih, selampit simpei, dan roda pedati.

Keunikan Industri batik Incung di Kota Sungaipenuh adalah industri batik yang mampu memproduksi aksara Incung menjadi motif batik yang membuat Sungaipenuh mempunyai ciri khas tersendiri. Sehingga memperkenalkan identitas daerah, salah satunya adalah motif Incung, karena motif ini merupakan aksara Kerinci Kuno. Oleh sebab itu, karena sudah diterapkan di dalam motif batik membuat masyarakat mengetahui kembali tentang aksara Incung. Selain itu, dengan adanya batik motif Incung ini juga memperkuat identitas kepribadian bangsa, khususnya masyarakat Kota Sungaipenuh dalam memperkenalkan identitas budaya suku Kerinci melalui media batik ini.

\section{Kota Sungaipenuh sebagai Kota Industri Batik Incung}

Kota Sungaipenuh merupakan pusat perkembangan industri batik Incung. Letak dari Kota Sungaipenuh sangat strategis yaitu dikelilingi oleh Kabupaten Kerinci. Sebelum adanya otonom Kota Sungaipenuh menjadi Ibukota Kabupaten Kerinci dengan mengalami perkembangan yang pesat.
Kota Sungaipenuh dijadikan oleh pemerintah sebagai pusat pendidikan pada wilayah Barat Provinsi Jambi dengan pusat pendidikan tinggi seperti Institut Agama Islam Negeri (IAIN) Kerinci, Sekolah Tinggi Ilmu Ekonomi Sakti Alam Kerinci, Sekolah Tinggi IImu Administrasi Sakti Alam Kerinci, Akademi Manajemen Informatika dan Komputer Depati Parbo, Akademi Keperawatan Bina Insani Sakti, Sekolah Tinggi Ilmu PendidikanMuhammadiyah, dan Sekolah Tinggi Ilmu Tarbiyah. Selain dijadikan sebagai pusat pendidikan, Kota Sungaipenuh juga dijadikan sebagai pusat perdagangan bagi daerah disekitarnya dengan memiliki beberapa pusat perbelanjaan, seperi Kicai Plaza merupakan pusat perbelanjaan modern yang menjadi salah satu Landmark kota, Pasar Beringin Jaya merupakan pusat perbelanjaan lama di Kota Sungaipenuh, dan Pasar Tanjung Bajure sebagai pasar kebutuhan pokok, atau pasar induk Kota Sungaipenuh (Veronika, 2015).

Sementara itu, Kota Sungaipenuh tidak hanya dijadikan sebagai pusat pendidikan dan perdagangan, tetapi juga dijadikan sebagai pusat industri batik. Hal ini tidak terlepas dari letak Administratif Kota Sungaipenuh yang dikelilingi oleh Kabupaten Kerinci yang menjadikan wilayah Kota Sungaipenuh sebagai wilayah sentral yang berpengaruh baik di bidang ekonomi, pendidikan dan budaya. 
Kota Sungaipenuh sebagai sentra industri batik Incung sudah dimulai sejak awal berdirinya industri batik di Kerinci tahun 1995 karena pada tahun sebelumnya sudah melakukan pelatihan yang diselenggarakan oleh pemerintah Kabupaten Kerinci yang pada saat itu Bupati Kerinci adalah Bambang Sukowinarno dengan membentuk beberapa sanggar batik seperti sanggar batik Karang Setio dan sanggar batik Puti Kincai serta Limo Luhah, Puti Masurai, Iluk Rupo, dan Salon Suhak. Namun, karena terjadinya krisis moneter tahun 1997, maka banyak industri yang gulung tikar termasuk industri batik Incung di Kota Sungaipenuh dengan menyisakan dua sanggar batik yang mampu bertahan yaitu sanggar batik Karang Setio dan sanggar batik Puti Kincai(Ekspres, 1999).

Perkembangan industri batik Incung di Kota Sungaipenuh mencapai puncak kemajuan yaitu setelah dikeluarkannya surat edaran oleh Walikota Sungaipenuh untuk mengembangkan motif khas Sungaipenuh yaitu aksara Incung. Sehingga, setelah dikeluarkannya surat edaran tersebut serta dilakukan pelatihan kepada masyarakat Kota Sungaipenuh, maka banyak sanggar batik yang berdiri di Kota Sungaipenuh yaitu sebanyak 8 sanggar batik. Berikut pada tabel 1 persebaran industri batik di Kota Sungaipenuh:

Tabel 1. Persebaran Industri Batik di Kota Sungaipenuh

\begin{tabular}{|c|c|c|c|c|}
\hline $\begin{array}{l}\mathrm{N} \\
\mathrm{O}\end{array}$ & Jenis & $\begin{array}{l}\text { Nama } \\
\text { Sanggar }\end{array}$ & Alamat & $\begin{array}{l}\text { Kecamata } \\
\mathrm{n}\end{array}$ \\
\hline \multirow[t]{2}{*}{1} & \multirow{2}{*}{$\begin{array}{l}\text { Pewarna } \\
\text { sintetis }\end{array}$} & $\begin{array}{l}\text { Puti } \\
\text { Kincai }\end{array}$ & $\begin{array}{l}\text { Lawang } \\
\text { Agung }\end{array}$ & $\begin{array}{l}\text { Sungaipen } \\
\text { uh }\end{array}$ \\
\hline & & $\begin{array}{l}\text { Karang } \\
\text { Setio }\end{array}$ & $\begin{array}{l}\text { Larik } \\
\text { Rio } \\
\text { Jayo }\end{array}$ & $\begin{array}{l}\text { Sungaipen } \\
\text { uh }\end{array}$ \\
\hline \multirow{7}{*}{2} & \multirow{7}{*}{$\begin{array}{l}\text { Pewarna } \\
\text { Alami }\end{array}$} & Incung & $\begin{array}{l}\text { Larik } \\
\text { Pantai }\end{array}$ & $\begin{array}{l}\text { Sungaipen } \\
\text { uh }\end{array}$ \\
\hline & & $\begin{array}{l}\text { Daun } \\
\text { Sirih }\end{array}$ & $\begin{array}{l}\text { Sumur } \\
\text { Anyir }\end{array}$ & $\begin{array}{l}\text { Hamparan } \\
\text { Rawang }\end{array}$ \\
\hline & & Incoang & $\begin{array}{l}\text { Larik } \\
\text { Pantai }\end{array}$ & $\begin{array}{l}\text { Sungaipen } \\
\text { uh }\end{array}$ \\
\hline & & Selampit & Larik & Hamparan \\
\hline & & Simpei & $\begin{array}{l}\text { Panjan } \\
\mathrm{g}\end{array}$ & Rawang \\
\hline & & $\begin{array}{l}\text { Keluk } \\
\text { Paku }\end{array}$ & $\begin{array}{l}\text { Desa } \\
\text { kampu } \\
\text { ng } \\
\text { Tengah }\end{array}$ & Koto Baru \\
\hline & & $\begin{array}{l}\text { Pandan } \\
\text { Manggur } \\
\text { ai }\end{array}$ & $\begin{array}{l}\text { Pondok } \\
\text { Agung }\end{array}$ & $\begin{array}{l}\text { Pondok } \\
\text { Tinggi }\end{array}$ \\
\hline
\end{tabular}

Sumber: DISPERINDAG Kota Sungai Penuh, 2017.

Berdasarkan tabel di atas didapatkan bahwa terdapat delapan sanggar batik yang masih aktif di Kota Sungaipenuh dengan menggunakan jenis pewarnaan yang berbeda-beda. Sanggar batik Puti Kincai dan Karang Setio menggunakan jenis pewarnaan sintetis sedangkan sanggar lainnya seperti Incung, Daun Sirih, Incoang, Selampit Simpei, Keluk Paku dan Pandan Mangurai menggunakan pewarnaan alami.

Pusat dari industri batik Incung adalah di Kota Sungaipenuh. Dijadikannya Kota Sungaipenuh sebagai pusat industri batik Incung juga karena peran walikota Sungaipenuh dengan mengeluarkan Surat Edaran Wali Kota Sungaipenuh No. 510/71/III.2/Koperindag-ESDM/ 2013, tentang Penggunaan Produk Batik Motif Khas Kerinci, Sungaipenuh tanggal 8 Februari 2013. 
Gambar 1. Peta persebaran Industri Batik di Kota Sungaipenuh

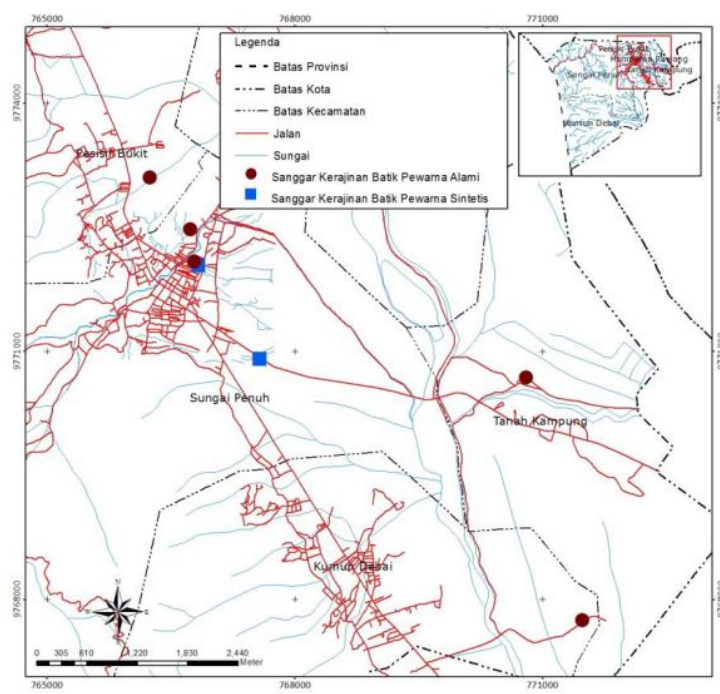

Sumber: Hasil Observasi, 2017.

Dipetakan oleh: Penulis

Surat edaran ini dibuat untuk mengembangkan batik khas Sungaipenuh dengan menggunakan aksara Incung sebagai motif utamanya. Surat edaran yang dikeluarkan oleh Walikota Sungaipenuh ini menerapkan sejumlah kebijakan, seperti menggunakan pakaian motif batik khas Kota Sungaipenuh setiap hari Kamis, pengadaan dan penjualan batik dengan menghubungi pemilik sanggar batik secara langsung, turut mempromosikan pemakaian pakaian batik khas Kota Sungaipenuh di lingkungan SKPD, UPTD dan masyarakat sekitar, misalnya sekolah dan organisasi masyarakat. Selain itu, setiap nama jalan yang ada di Kota Sungaipenih dituliskan menggunakan aksara Incung. Hal ini dilakukan agar masyarakat mengenal bentuk aksara Incung itu sendiri.
Gambar 2. Kota Sungaipenuh dijadikan sebagai motif batik Incung

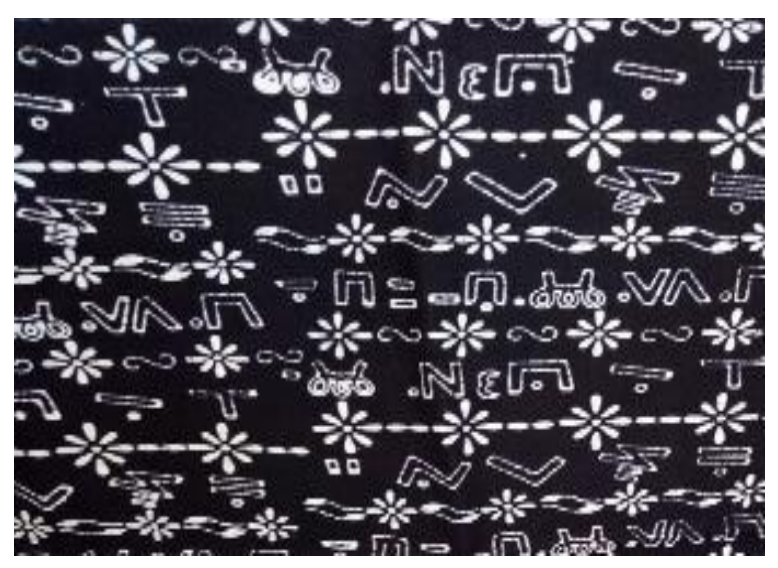

(Sumber: Photo milik Erni Yusnita dan diambil oleh Nandia Pitri 23 Maret 2018.)

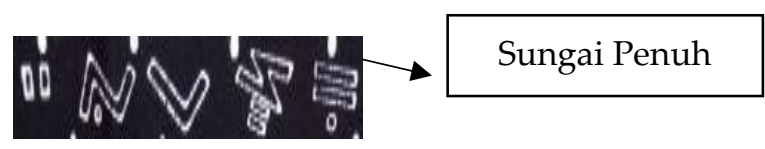

Pada gambar di atas berusaha untuk menjelaskan tentang Kota Sungaipenuh merupakan tempat memproduksi kain batik ini. sehingga, tulisan Kota Sungaipenuh dimuatkan di atas kain mori di atas. Namun, cara membacanya pada gambar di atas berlawanan arah jarum jam atau seperti membaca Al-Quran.

\section{Pengrajin Perempuan Batik Incung}

Berubahnya sistem ekonomi masyarakat dari pertanian ke industri merupakan dampak modernisasi. Sistem ekonomi industri banyak berkembang di wilayah pedesaan karena mempunyai potensi untuk berkembangnya industri karena masyarakat beranggapan bahwa bekerja di pabrik industri mampu untuk menghasilkan pendapatan lebih cepat 
daripada harus menunggu hasil panen pertanian mereka.

Batik mampu menembus masuk ke dalam industri setelah batik dianggap sebagai kebudayaan yang mempunyai potensi untuk dikembangkan. Sehingga, hal ini menyebabkan pengrajinnya memiliki perbedaan pada masa kelampauan dengan masa modernisasi. Dahulunya para pengrajin dituntut untuk mengubah barang dasar menjadi barang jadi. Namun setelah memasuki masa modernisasi maka para pengrajin batik lebih dituntut untuk memenuhi kebutuhan pasar. Hal ini menyebabkan pengrajin harus memiliki keterampilan produksi dan perdagangannya juga mempunyai inovasi baru dengan beragam bentuk. Pada awal perkembangannya, batik hanya digunakan sebagai busana atau pakaian, namun sekarang disesuaikan dengan kebutuhan konsumen. Hal inilah merupakan cara awal yang dilakukan untuk proses pelestarian batik dengan memunculkan rasa ingin memiliki dan berniat untuk melestarikannya.

Kegiatan wirausaha yang dilakukan oleh pengrajin batik pada masa sekarang memiliki manajemen yang baik seperti perumusan tujuan, pembentukan usaha, dan merencanakan strategi. Sehingga pengelolaan industri mampu untuk memikirkan kekuatan, kelemahan, peluang dan ancaman sehingga mampu untuk mengatasi kekurangan dalam meningkatkan kemampuan produksi.
Perkembangan industri batik Incung di Kota Sungaipenuh di dominasi oleh pengrajin perempuan, kegiatan membatik yang dilakukan oleh para pengrajin perempuan tersebut di rumahnya masingmasing dan ada pula yang melakukan kegiatan membatik di rumah juragan batiknya. Bagi perempuan di Kota Sungaipenuh menjadikan aktivitas membatik sebagai kegiatan rutin disamping sebagai ibu rumah tangga. Latar belakang perempuan di Kota Sungaipenuh ikut serta dalam membatik karena faktor ekonomi. Oleh sebab itu, untuk berperan dalam pembangunan maka perempuan dituntut untuk memiliki sikap mandiri dalam mengapresiasikan seluruh potensi yang dimiliki.

Zubaidah menjelaskan bahwa membatik memerlukan ketekunan, keuletan dan kesabaran. Sehingga membatik cocok dengan kepribadian perempuan yang sabar dan tekun dalam mengerjakan sesuatu. Selain itu, perempuan yang bekerja sebagai pengrajin batik masih bisa membagi waktunya untuk keperluan rumah tangga dan pekerjaannya(Zubaidah, 2018).Zubaidah juga menjelaskan bahwa kemampuan membatik yang dimiliki oleh perempuan pengrajin batik ini dapat dilihat berdasarkan lamanya pengalaman dalam pembuatan batik.

Elita Jaya merupakan salah satu perempuan yang awalnya bekerja sebagai pembatik kemudian menjadi pengusaha 
batik. Awal mula Elita Jaya menjadi pembatik sekitar tahun 1992 ia menjadi buruh batik, kemudian seiring berjalannya waktu Elita Jaya mulai terampil dan mahir membuat batik. Akhirnya Elita Jaya membuka usaha batik, dalam pembuatan batik Elita Jaya dibantu 5 orang karyawannya. Menurut Elita Jaya pada tahun 1995 batik hanya dikerjakan beberapa orang saja. Kemudian perempuan yang ada di Kota Sungaipenuh mulai tertarik untuk membatik pada tahun 2011 setelah dilakukan pelatihan besar-besaran oleh pemerintah Kota Sungaipenuh. Elita Jaya sebagai pengusaha batik, membiarkan pembatik yang bekerja di industrinya untuk membuat motif- motif batik yang diinginkan, tetapi walaupun sesuai dengan keinginan motif Incung harus dijadikan sebagai motif utama dalam membuat batik ditempatnya(Jaya, 2018).

Kegiatan membatik selalu identik dengan perempuan, hal ini dikarenakan membatik cocok dengan sikap dan sifat wanita yang halus. Perempuan cenderung lebih sabar, halus dan teliti dalam menyelesaikan suatu pekerjaan, termasuk juga dalam pembuatan batik. Penggoresan malam pada kain mori bukan kegiatan yang mudah, karena membutuhkan keterampilan membatik dan kesabaran dalam mengikuti motif yang ada pada kain mori. Menurut (Yusnita, 2018), bahwa pembuatan batik pada zaman dahulu dengan zaman sekarang itu berbeda. Pada zaman dahulu ibu rumah tangga menghasilkan batik hanya untuk mengisi waktu luang di rumah. Kegiatan sehari-hari yang mereka lakukan untuk mengisi kesibukan adalah dengan membuat batik. Biasanya para ibu rumah tangga membuat batik untuk digunakan sebagai pakaian. Akan tetapi sekarang batik dihasilkan untuk keperluan konsumen, motif dan warna mengikuti permintaan dari konsumen. Para wanita menjadikan membatik sebagai lahan pekerjaan untuk membantu perekonomian keluarga. Gusmiarti warga Desa Permanti, Kecamatan Pondok Tinggi, Kota Sungaipenuh merupakan salah satu pembatik wanita yang bekerja sebagai pembatik di industri batik “Incung” milik Erni Yusnita keterampilan membatik yang dimiliki Gusmiarti menjadikan ia bisa membantu perekonomian keluarganya, sehingga ia dan keluarganya tidak tertatih-tatih dalam memenuhi kebutuhan hidup seharihari. Suami Gusmiarti merupakan buruh panen padi yang mendapatkan upah $\mathrm{Rp}$ 50.000 per hari. Melalui keterampilan membatik yang dimiliki Gusmiarti, maka bisa digunakan untuk mencukupi kebutuhan sehari-hari dan menyekolahkan anaknya (Gusmiarti, 2018).

Selain Gusmiarti, Zubaidah (52) warga Desa Pondok Tinggi juga merupakan pembatik perempuan yang bekerja di industri batik “Incung". 
Keterampilan membatik yang dimiliki Zubaidah, menjadikan ia mampu meringankan perekonomian keluarganya, karena sebelum Zubaidah menjadi pembatik awalnya ia hanya ibu rumah tangga saja. Sehingga hal ini menjadikan ia dan keluarganya bisa mencukupi kebutuhan keluarga, karena sebelumnya situasi perekonomian keluarga Zubaidah kurang baik, dikarenakan suami Zubaidah hanya bekerja sebagai tukang bangunan(Zubaidah, Pengrajin Batik, 2018).Sapera Desi menjelaskan bahwa sehari-hari ia selalu bekerja dengan ditemani canting cap dan kain mori yang siap untuk diberi motif batik. Sapera Desi bekerja dari pukul delapan pagi sampai pukul empat sore. Sebelum memulai bekerja di industri batik hal yang dilakukan Sapera Desi adalah menyelesaikan segala pekerjaan rumah tangganya terlebih dahulu. Sejak tahun 2000-an Sapera Desi sudah bekerja sebagai pembatik. Pembagian kerja antara menyelesaikan pekerjaan rumah tangga dengan menyelesaikan pekerjaan sebagai pembatik sudah merupakan hal yang biasa ia lakukan (Desi, 2018).

\section{PENUTUP}

\section{Simpulan}

Aksara Incung dijadikan sebagai motif batik karena ingin mengembangkan kearifan lokal yang ada di Kota Sungaipenuh sehingga dapat dikenal oleh masyarakat luas dengan menerapkan aksara Incung ke atas kain mori menjadi motif batik. Hal ini juga didorong dengan bantuan pemerintah dengan mengutuskan anggota dari Departemen Perindustrian Provinsi Jambi dalam menggunakan aksara Incung sebagai motif batik di Kota Sungaipenuh.

Kota Sungaipenuh sebagai pusat berkembangnya industri batik Incung memiliki potensi besar dalam memajukan kerajinan batik dan mampu membuat batik berkembang pesat. Selain sebagai pusat berkembangnya batik Incung, Kota Sungaipenuh juga merupakan pusat pendidikan dan perdagangan bagi Kota Sungaipenuh dan Kabupaten Kerinci, sehingga dengan letaknya yang strategis membuat masyarakat banyak berkunjung ke Kota Sungaipenuh baik untuk pemenuhan keperluan pendidikan maupun untuk ekonomi. Hal inilah yang menjadi penyebab dikembangkannya industri batik Incung di Kota Sungaioenuh. Sementara itu, dijadikannya Kota Sungaipenuh sebagai pusat industri batik Incung tidak terlepas dari peranan pemerintah dengan mengeluarkan surat edaran untuk mengembangkan batik khas Sungaipenuh dengan menggunakan aksara Incung sebagai motif utama. Selain peran dari pemerintah setempat untuk mengembangkan industri batik Incung di Kota Sungaipenuh juga melibatkan beberapa golongan masyarakat seperti para pengrajin yang berasal dari Kota Sungaipenuh, serta masyarakat setempat 
yang mendukung dalam pengembangan industri batik Incung di Kota Sungaipenuh.

\section{Saran}

Kota Sungaipenuh merupakan kota yang mempunyai potensi baik sumber daya alam maupun sumber daya manusia, yang mampu untuk dikembangkan dan menambah wawasan untuk tatanan kota lainnya khususnya di wilayah Kerinci dan Sungaipenuh.

\section{Daftar Pustaka}

Desi, S. (2018, September 20). Pengrajin Batik. (N. Pitri, Pewawancara)

Djakfar, I., \& Indra, I. (2001). Menguak Tabir Prsejarah di Alam Kerinci. Sungaipenuh: Pemerintah Kabupaten Kerinci.

Ekspres, J. (1999, Juni 07). Karang Setio Batik Kerinci yang Tetap Eksis. Jambi, Jambi, Indonesia: Jambi Ekspres.

Gottschalk, L. (2007). Mengerti Sejarah. Yogyakarta: Ombak.

Gusmiarti. (2018, Juli 28). Pengrajin Batik. (N. Pitri, Pewawancara.

Jaya, E. (2018, Agustus 24). Peilik Sanggar Batik Karang Setio. (N. Pitri, Pewawancara)

Kebudayaan, D. P. (2003). Sastra Incung Kerinci. Sungaipenuh: Dinas Pariwisata dan Kebudayaan.

Kompas. (19994, Maret 13). Ida Maryanti: Memindahkan 'Encong' dan Kerinci ke atas Kain Mori. Jambi, Jambi, Indonesia: Kompas.
Kozok, U. (2006). Kitab Undang-Undang Tanjung Tanah: Naskah Melayu yang Tertua. Jakarta: Yayasan Obor.

Maryanti, I. (2018, Mei 28). Rumusan Awal Motif Incung. (N. Pitri, Pewawancara)

Musman, A., \& Arini, A. B. (2011). Batik: Warisan Adiluhung Nusantara. Yogyakarta: Andi.

Sjamsuddin, H. (2007). Metodologi Sejarah . Yogyakarta: Ombak.

Veronika, M. (2015). Administrasi Pemerintahan Daerah: Kota Sungaipenuh pada Masa Otonomi Daerah (2008-2014). Padang: Program Studi Pendidikan IImu Pengetahuan Sosial Konsentrasi Pendidikan Sejarah Universitas Negeri Padang.

Yusnita, E. (2018, Mei 15). Pemilik Sanggar Batik Incung. (N. Pitri, Pewawancara)

Zakaria, I., \& Syaputra, D. (2017). Khazanah Aksara Incung. Sungaipenuh: Dinas Kebudayaan dan Pariwisata Kota Sungaipenuh.

Zed, M. (1999). Metodologi Sejarah. Padang: Universitas Negeri Padang.

Zubaidah. (2018, Juli 28). Pengrajin Batik. (n. Pitri, Pewawancara).

Zubaidah. (2018, Juli 28). Perempuan Pembatik. (N. Pitri, Pewawancara). 
Aksara Incung sebagai Pembelajaran Berbasis Kearifan Lokal, Nandia Pitri, 29-40 